
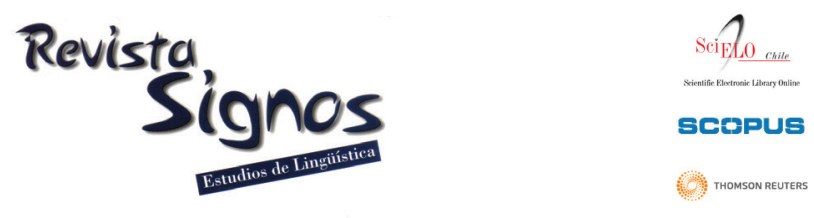

\title{
Communication strategies used by different level L2 English learners in oral interaction ${ }^{*}$
}

\author{
El uso de estrategias de comunicación de aprendices de inglés \\ como L2 con diferentes niveles de competencia en un \\ contexto oral interactivo
}

\author{
Maritza Rosas Maldonado \\ Universidad Andres Bello \\ CHILE \\ maritza.rosas@unab.cl
}

Recibido: 06-VI-2014 / Aceptado: 27-VII-2015

\begin{abstract}
This study aims to examine the different communication strategies (CSs) EFL learners employ when communicating orally, and determine the relationship between the learners' proficiency level and their CS use. Spoken data from three conversations held by Spanish learners of English of different levels were analysed in order to determine the type of CSs they used when interacting with a native speaker (NS) in an informal environment outside the classroom. The identification of the CSs was carried out following Dörnyei and Körmos' taxonomy (1998). Overall results show that there is an association between the learners' proficiency level and their CS usage. Results from a detailed analysis confirmed this relationship and revealed that the learners' linguistic competence is not only related to the frequency of the CSs used but mostly to the type of CS.
\end{abstract}

Key Words: Communication strategies, proficiency, interaction, L2 communication, taxonomy. 


\section{Resumen}

El objetivo de este estudio fue analizar las diferentes estrategias de comunicación (EsC) que utilizan aprendices de inglés como L2 al comunicarse oralmente, y determinar la relación entre la competencia lingüística de estos estudiantes y el uso de las EsC. Se analizó un corpus oral obtenido de tres conversaciones entre estudiantes de inglés de distintos niveles de competencia con el propósito de descubrir el tipo de EsC que éstos utilizan al interactuar con un hablante nativo en un ambiente informal fuera del aula. La identificación de las EsC utilizadas se realizó mediante la taxonomía propuesta por Dörnyei y Körmos (1998). Desde un punto de vista general los resultados muestran que existe una asociación entre el nivel de competencia lingüística de los estudiantes y las EsC que éstos utilizan. Esto fue corroborado mediante un análisis más detallado de los datos que demostró una relación no sólo entre el nivel de competencia y la frecuencia de uso de las EsC sino principalmente con el tipo de estrategias utilizadas por cada nivel.

Palabras Clave: Estrategias de comunicación, competencia, interacción, comunicación en L2, taxonomía.

\section{INTRODUCTION}

The various mental processes that L2 learners go through during their IL development have become clearer thanks to Selinker's proposal (1972) of the Interlanguage (IL) Theory as well as Cognitivist (Ellis \& Robinson, 2008) and Interactionist theories (Long, 1980) of language learning. It is within this context of IL development that much interest has been given to the way that L2 English learners try to communicate in the target language (TL), and thus to the communication strategies (hereafter CSs) used to overcome the difficulties which arise when attempting to produce the language (Tarone, 1977; Corder, 1983; Færch \& Kasper, 1983; Poulisse, 1990; Kellerman, Ammerlaan, Bongaerts \& Poulisse, 1990). These CSs have been found to be useful tools for L2 learners to fill the gap between their communicative needs and the limited resources in the L2, thus leading them to find a balance between what they learn in the classroom, and the resources necessary to better interact in the L2 (Tardo, 2005).

This paper focuses on the CSs utilised by Spanish learners of English with different proficiency levels when interacting with an English native speaker (NS) outside the classroom setting. The term 'second' language will be indistinctively used to refer to 'second' and 'foreign' language following Ellis definition (1997: 3): "any language that is learned subsequent to the mother tongue, independently of the conditions in which the language is being learned". The final aim of this study was to identify the CSs used by these learners in an interactional context and to determine a possible relationship between their proficiency level and CS usage. The identification of these learners' strategic use of the L2 as related to their proficiency level - thus the identification 
of their communication problems - may ultimately lead to the improvement of the teaching and learning of English hence helping learners in the transition between their IL and the L2.

\section{Communication strategies}

There have been various theories of Second Language Acquisition (SLA) which have emphasised the importance of CSs, such as, Cognitivist, Interactionist, Interlanguage as well as Collaborative theories. In addition, these strategies find support in the area of Teaching English as a Foreign Language (TEFL) through methodological approaches such as the Communicative Language Teaching and the Task-based Language Approach. In both these fields, CSs are seen as facilitators in the process of communicating orally in the target language.

The term 'communication strategies' was first coined by Selinker (1972) when referring to these mechanisms as one of the five central processes that occur in the learning of a second language. Later, researchers such as Váradi (1973) and Tarone (1977) would propose the first definitions. These initial studies focused mainly on defining and classifying these strategies through the creation of taxonomies which would later serve for their analysis and categorisation (Tarone, 1977; Corder, 1983; Færch \& Kasper, 1983). In addition to this, Canale and Swain (1980) included these strategies in their model of 'communicative competence' as one of its subcomponents, that of 'strategic competence'; hence, also emphasising their importance in second language learning.

\subsection{Previous research and the proficiency factor}

Research in this area has focused on investigating the use of CSs in relation to various factors, such as the learners' proficiency level (Bialystok \& Fröhlich, 1980; Paribakht, 1984; Safont Jorda, 2001; García Núñez, 2006; Prebianca, 2009) and the task used for elicitation purposes (Poulisse \& Schils, 1989; Rabab'ah \& Seedhouse, 2004). Consideration has also been given to the influence of the learners' L1 (Fernández Dobao, 2001; Rabab'ah \& Bulut, 2007), the situational context in which the CSs are employed (Williams, Inscoe \& Tasker, 1997) as well as the learning context (Lafford, 2004), amongst others.

The empirical studies which have focused on the proficiency factor have demonstrated a relationship between learners' proficiency levels and their use of CSs (Fernández Dobao, 2001, 2004; Safont Jordá, 2001; Littlemore, 2003; García Núñez, 2006; Prebianca, 2009). It has been observed that those learners with a lower level of L2 competence need to resort to a higher number of CSs due to the relatively small number of linguistic resources available. More proficient learners, on the other hand, do not seem to make much use of these strategies due to their broader L2 linguistic repertoire. In addition to the CS frequency -as related to the learners' 
competence- the learners' selection of CSs has also been found to correspond with their level of proficiency (Bialystok \& Fröhlich, 1980; Hyde, 1982; Paribakht, 1984; Chen, 1990; Fernández Dobao, 2001). Less proficient learners have been observed as resorting to CSs which are more related to their L1, such as, 'literal translation', 'codeswitching' and 'foreignising' as well as to reduction/avoidance mechanisms, such as, 'message abandonment/reduction'. In contrast, more proficient learners seem to rely on more cognitively demanding mechanisms (achievement CSs) like 'self-repairs', 'approximation', 'paraphrase' and 'restructure'. Additionally, time-gaining mechanisms have also been found as more related to lower levels as L2 processing requires more attentional resources and time than is needed when using an L1 (Prebianca, 2009; Wannaruk, 2003). Most of these studies; however, have limited their analysis to the lexical problems faced by learners in L2 communication. In addition, the data elicitation procedures followed have favoured less naturalistic settings which do not necessarily entail the same communication demands as in everyday conversation.

Fernández Dobao (2001), for example, investigated the lexical CSs (achievement \& reduction/avoidance) used by different level learners of English as L2 by following early CS taxonomies, those of Corder (1978, as cited in Færch \& Kasper, 1983) and Tarone (1977). The data elicitation was conducted by the carrying out of three different tasks, a description and a picture story performed by the learners individually, and a conversation activity carried out with the researcher as the interlocutor. The main finding of this study, in relation to the proficiency factor, corresponded with most evidence in that the lower level learners relied more often on avoidance/reduction CSs while the more advanced learners favoured the use of achievement CSs. She also analysed the influence of other factors (task and L1), but no substantial results were observed, although the researcher acknowledged a possible influence of the task type on the learners' use of CSs. One aspect which was found beneficial for the confirmation of the CS usage was the retrospective interview conducted after the learners' performance of the different tasks. García Núñez (2006) also analysed the lexical CSs used by English learners belonging to elementary and intermediate levels by drawing on Færch and Kasper's framework (1983). The tasks used for the data collection consisted of an object description task and a semi-structured interview in a learner-interviewer setting. As opposed to the above study, there was no post interview to confirm the learners' use of CSs. Overall results did not show marked differences between levels, but the more in-depth qualitative analysis demonstrated some differences which were also concurrent with other studies. Elementary levels tended to use reduction and L1-based mechanisms whereas intermediate levels were more inclined to use achievement devices (paraphrase and restructure). He also concluded that the task type seemed to have an effect on the learners' behaviour. Prebianca (2009) examined the effects of the proficiency level by looking at preintermediate, intermediate and advanced learners' use of CSs. The data was collected through the realisation of three description type of tasks carried out individually by the learners. In contrast to previous studies, Prebianca's (2009) research drew on 
a broader analytical framework, that of Dörnyei and Kormos (1998). Her results, however, differed from these studies since there were no substantial differences in the learners' CS usage across levels, an outcome which she concluded may have been due to the monologic nature of the tasks used, which seemed to produce fewer demands. Balharry's study (2006) focused on the proficiency and task effects on the learners' use of lexical CSs by drawing on Poulisse's taxonomy (1990). She examined the use of CSs in different times by means of a longitudinal part of the study composed by two EFL college students, and a cross sectional part formed by four students. The tasks used for the data elicitation were a story retelling activity and an interview, both tasks carried out between the learner and the researcher acting as interviewer. The results did not show a clear pattern of CS usage, the only constant figure being, as concluded by Balharry (2006), the use of transfer CSs by the less proficient learners, a finding which partly corresponds with most studies. She acknowledged the inconsistencies in the results as due to the small sample, especially for the longitudinal part of the study, in addition to the use of a less comprehensive taxonomy and the lack of a retrospective interview to confirm the learners' strategic behaviour. Finally, in a more recent study, Yang and Gai (2010) also examined the proficiency effects on the use of CSs by Chinese learners of English by following Færch and Kasper's taxonomy (1983). In contrast to most research, they were also interested in investigating the learners' perception on their use of CSs so as to determine the role of the learners' awareness of their strategic L2 communication. In order to examine the learners' attitude towards the CSs and the frequency of CS usage, a questionnaire was administered to 89 students from different levels, data which was complemented with an interview conducted to 10 of these students. The main finding showed a more frequent use of reduction CSs in general, but the learners' perception on the use of reduction and achievement CSs varied according to level. Low level learners showed a neutral attitude towards reduction mechanisms, while higher levels tended to hold a negative attitude. This study moved away from the more qualitative analyses so far carried out which focused on the learners' oral communication, thus on the way they try to get their message across by means of CSs. Focusing on the learners' perception only does not provide further data on the proficiency effects, but mostly on the learners' knowledge of the CSs. Yang and Gai (2010) acknowledged the study limitations regarding the narrow scope of CSs examined by means of the framework used in addition to a lack of retrospective methods of enquiry.

As evidenced in the literature reviewed most research has focused on analysing the CSs used by learners to overcome the lexical problems experienced in L2 communication, thus restricting the analysis to this type of difficulty. Additionally, most of the tasks used for the elicitation of the learners' CS usage involve a more artificial setting, with the learner carrying out an activity on their own or in interaction with the researcher in an interview type of context. This points to the scarce research related to the use of CSs in interactional contexts that is, in learnerlearner or learner-NS communication (Labarca \& Khanji, 1986; Fernández Dobao \& 
Palacios Martínez, 2007). In view of this, this study aims at analysing the learners' strategic behaviour in an interactional, less artificial context by eliciting the learners' CS usage by means of free conversations between different level students and a NS interlocutor. In addition, the focus of analysis has been extended to other problematic areas by drawing on a wider analytical framework. Hence, the definition proposed by Tarone (1981: 288) has been here favoured as it recognises the role of the interlocutor in the process of strategic communication: "the term [CS] relates to a mutual attempt of two interlocutors to agree on a meaning in situations where requisite meaning structures do not seem to be shared". In order to broaden the scope of analysis the taxonomy of CSs proposed by Dörnyei and Körmos (1998) has been followed for its most comprehensive and up-to-date classification of these mechanisms. In addition to the interactional aspect of communication which was incorporated through particularly one of its categories.

Finally, it is worth adding that there is a lack of research in this area in our local educational context, with a few exceptions (Doddis, Novoa, Tabillo, 2001-2003; Balharry, 2006), a fact which emphasises the possible contributions of this study. There is a need for exploring this issue locally in order to gain insight on the problems that EFL learners encounter when trying to communicate in the L2, and how these strategies may facilitate this process and thus the learners' progress toward the TL.

\section{Methods}

\subsection{Study}

The present study was the result of a minor thesis work conducted at a university located in the south of Chile. The main purpose was to explore the strategic behaviour of different proficiency level learners of English when interacting with a NS outside the classroom setting. This idea originated from personal experience as an English Tutor at this university and by observing the many difficulties EFL learners experience when attempting to communicate in the L2. This study was descriptive, correlational and cross-sectional with quantitative and qualitative research methods. The variables analysed were the learners' proficiency level -which was determined by their attendance to a specific language class group- and their use of CSs when interacting in English as L2.

\subsection{Participants}

Undergraduate students from a southern university in Chile were selected as the participants in this study. In addition, an English NS assistant working at the same university at the time participated as interlocutor. A total of 9 subjects, 3 male and 6 female students whose ages ranged from 18 to 23 years, were randomly selected from their English Language modules as belonging to three different proficiency levels. Thus, their classification within this class determined their linguistic competence for 
the present study. These would be the levels they were later assigned to for the data collection. Three students were randomly selected from each of the English Language modules (Lengua Inglesa I, II y III), which, as mentioned by the English tutors, were expected to have a proficiency level equivalent to Beginner (Language Module I), Pre-intermediate (Language Module II) and Intermediate levels (Language Module III). These Modules were given in first, second and third year, respectively. Thus, the final sample was formed by two female and one male students in each group.

\subsection{Instruments}

A brief questionnaire addressing the students' previous linguistic background in relation to English learning was administered to those students attending the Language modules mentioned above, in their first, second and third year (see Appendix). The purpose was to find out how much knowledge of the L2 they already possessed before entering university, thus controlling for any other factors which may have negatively influenced the results of this study. Afterwards, information relating to the students' attendance to this course was gathered, in consultation with the English language tutors, in order to make sure that the prospective participants' L2 competence -demonstrated by their classification within the language classwas the result of a similar linguistic 'input'. Once these factors had been controlled, three students from each language class were randomly selected (Beginners, Preintermediate, Intermediate).

The main instrument used for the data collection consisted of a free-conversation activity used to stimulate the learners' interaction with a NS in each level. It was expected that this kind of free activity would simulate an everyday type of conversation.

\subsection{Procedures}

Prior to the data collection, some important ethical issues were addressed by informing the participants about the aims of this study -although in general terms so as not to influence their performance- and that their conversation would be video recorded for research purposes. Their authorisation was therefore obtained through a consent form. Later, for the data collection sessions, the participants were invited to a social meeting with an English speaker with whom they would have the opportunity to practice the language. They were requested to speak English as much as possible as the NS spoke very little Spanish. The NS, on the other hand, was asked to speak only English and to also act as a moderator of the conversations, as far as possible, so as to promote a fairly equal number of turns as well as oral output. The data collection sessions were intentionally carried out outside the classroom setting, in order to create a more comfortable location which would also help to simulate an everyday like situation. There were three sessions where each group (level) of students interacted with the NS in a free conversation for approximately one hour. These sessions were video and audio recorded and immediately transferred to a laptop for 
their analysis. This analysis however considered only 30 minutes of recording since the time needed for the students to get used to this situation, and thus feel more comfortable to speak in the L2, was taken into account. Once the data was collected, it was transcribed and examined following Dörnyei and Körmos' taxonomy (1998), and some of the suggestions provided in the literature for the identification of these mechanisms (Fernández Dobao, 2001, 2004; Wonsawang, 2001). After a preliminary identification of the CSs used by the learners, the participants were contacted in order to elicit their retrospective comments in relation to their strategic communication and thus confirm this first analysis. For this, stimulated recall methodology was used in order to try to identify the participants' mental processes which would be impossible to observe otherwise, hence confirming the CSs used (Gass \& Mackey, 2000). This post interview was carried out in Spanish for the students to feel more comfortable and thus be able to explain their strategic behaviour in more detail. For this, the video recording plus the transcription of their conversation was shown to the students in each group so as for them to try to remember what problems they found when trying to communicate with the NS and how they thought they had solved those problems.

\subsection{Data analysis}

Once the data had been collected and transcribed, it was analysed by means of Dörnyei and Körmos’ Framework (See details below). This allowed for a preliminary identification of the CSs used by the learners. Later, with the confirmation of the participants' CS usage (through the post interview) it was possible to manually count the different CSs used by the learners in each level. This information was then inputted in the software 'Infostat' for the subsequent application of the statistical test Chi-square which would then demonstrate any association between the variables. The spoken data obtained was then qualitatively analysed by examining the participants' interactions with the NS plus their retrospective comments.

\subsubsection{Analytical framework}

The taxonomy proposed by Dörnyei and Körmos (1998: 356) was used for the analysis of the data. This classification follows a psycholinguistic approach based on Levelt's L2 model of speech production hence it is focused on the management of the four primary problem areas and how they relate to "the various phases of speech processing". These problem areas of L2 communication are classified into Problem-solving mechanisms (PSM) related to L2 resource deficit, which includes lexical, grammatical and phonological-articulatory PSM; PSM related to processingtime pressure (repetitions and pauses); PSM related to own-output problems (selfcorrections, asking check-questions), and PSM related to other-performance problems (meaning negotiations CSs). Figure 1 below presents these main categories with their corresponding descriptions. However, only those CSs most observed in this study, within each of the categories, will be presented and described to be subsequently 
illustrated and analysed in the following section. It should be noted that the original framework is composed of a total number of approximately 40 CSs.

Figure 1. Dörnyei and Kormos’ Taxonomy (1998: 169-178).

\begin{tabular}{|c|c|}
\hline $\begin{array}{l}\text { PSM related to L2 Resource Deficit } \\
\text { (RD) - C1 }\end{array}$ & $\begin{array}{l}\text { CSs employed when resource deficits hinder the planning and encoding of the } \\
\text { preverbal plan. This means that learners need to resort to these strategies because } \\
\text { of their limited command or lack of linguistic resources in the L2. }\end{array}$ \\
\hline \multicolumn{2}{|l|}{ Lexical PSM } \\
\hline Message abandonment & Leaving a message unfinished because of some language difficulty. \\
\hline \multicolumn{2}{|l|}{ Substitution PSM } \\
\hline Code-switching & $\begin{array}{l}\text { Including L1 or L3 words with L1 or L3 pronunciation in L2 speech; this may } \\
\text { involve stretches of discourse ranging from single words to whole chunks and } \\
\text { even complete turns. }\end{array}$ \\
\hline Foreignising & $\begin{array}{l}\text { Using a L1 or L3 word by adjusting it to L2 phonology (i.e., with a L2 pronuncia- } \\
\text { tion) or morphology. }\end{array}$ \\
\hline Literal Translation & $\begin{array}{l}\text { Translating literally a lexical item, an idiom, a compound word, or a structure from } \\
\text { L1 or L3 to L2. }\end{array}$ \\
\hline \multicolumn{2}{|l|}{ Appeals for help } \\
\hline Direct Appeal for help & $\begin{array}{l}\text { Turning to the interlocutor for assistance by asking an explicit question concerning } \\
\text { a gap in one's L2 knowledge. }\end{array}$ \\
\hline \multicolumn{2}{|l|}{ Micro conceptualization } \\
\hline Circumlocution & $\begin{array}{l}\text { Exemplifying, illustrating. Or describing the properties of the target object or ac- } \\
\text { tion. }\end{array}$ \\
\hline $\begin{array}{l}\text { PSM related to processing time } \\
\text { pressure }-\mathrm{C} 2\end{array}$ & $\begin{array}{l}\text { The various stalling mechanisms L2 learners employ in order to gain time and thus } \\
\text { be able to think of the necessary item/s for them to communicate. }\end{array}$ \\
\hline \multicolumn{2}{|l|}{ Pauses } \\
\hline Unfilled pauses & Remaining silent while thinking. \\
\hline Sound lengthening (drawling) & Lengthening a sound in hesitation. \\
\hline Fillers (lexicalised pauses) & $\begin{array}{l}\text { Using filling words or gambits to fill pauses, to stall, and to gain time in order to } \\
\text { keep the communication channel open and maintain discourse at times of dif- } \\
\text { ficulty. }\end{array}$ \\
\hline \multicolumn{2}{|r|}{ 2: } \\
\hline Self-repetition & Repeating a word or a string of words immediately after they were said. \\
\hline $\begin{array}{l}\text { PSM related to own-output prob- } \\
\text { lems - C3 }\end{array}$ & L2 deficiencies identified by the speaker in his/her own output. \\
\hline \multicolumn{2}{|l|}{ Self-correction } \\
\hline Error-repair & Making self-initiated corrections of accidental lapses in one's own speech. \\
\hline $\begin{array}{l}\text { PSM related to other-performance } \\
\text { problems - C4 }\end{array}$ & $\begin{array}{l}\text { meaning-negotiation mechanisms triggered by perceived problems in the interlocu- } \\
\text { tor's rather than in one's own speech. }\end{array}$ \\
\hline
\end{tabular}




\section{Analysis and discussion of results}

\subsection{Relationship between proficiency level and CS usage}

The aim of this study was to identify the CSs used by L2 English learners and to determine a possible relationship between their proficiency level and use of CSs. In order to do this, the total number of CSs was identified and classified per each level according to the CS categories, as presented in Table 1 below. The levels are represented as Level 1, Beginner; Level 2, Pre-intermediate and Level 3, Intermediate. Percentages have also been added for a clearer understanding of these overall results.

Table 1. Total results obtained for the three proficiency levels in relation to their use of each CS category.

\begin{tabular}{|l|l|l|l|l|l|l|l|l|l|}
\hline Level & \multicolumn{2}{l}{$\begin{array}{l}\text { C1 } \\
\text { L2 Resource D. }\end{array}$} & \multicolumn{2}{l|l}{$\begin{array}{l}\text { C2 } \\
\text { Processing T-P }\end{array}$} & \multicolumn{2}{l|l}{$\begin{array}{l}\text { C3 } \\
\text { Own-output PSM }\end{array}$} & $\begin{array}{l}\text { C4 } \\
\text { Other-perf.PSM }\end{array}$ & $\begin{array}{l}\text { Total No CSs per } \\
\text { level }\end{array}$ \\
\hline 1 & 201 & 40.6 & 72 & 34.6 & 33 & 25 & 31 & 59.6 & $337(38 \%)$ \\
\hline 2 & 160 & 32.3 & 49 & 23.6 & 38 & 28.8 & 7 & 13.5 & $254(28.6 \%)$ \\
\hline 3 & 134 & 27.1 & 87 & 41.8 & 61 & 46.2 & 14 & 26.9 & $296(33.1 \%)$ \\
\hline & 495 & $100 \%$ & 208 & $100 \%$ & 132 & $100 \%$ & 52 & $100 \%$ & 887 \\
\hline
\end{tabular}

Overall, the differences in the patterns of distribution are statistically significant ( $\mathrm{df}=6, \chi^{2}=39.70, p=0.01$ ) indicating differential use of the CS categories by the three levels, and therefore an association between the learners' proficiency level and their use of CSs. However, although the association coefficient between the variables is significant it reveals an association of medium intensity (0.206) as especially influenced by the results obtained for the category C4 (PSM related to otherperformance problems). This latter result may be related to the kind of interactional setting in which the CSs were elicited, which was based on a free conversation held between three students and a NS. It is probable that such an open-ended type of interaction might not have demanded much negotiation of meaning on the part of the participants as it may be expected in a more linguistically controlled type of setting or task (Pica, Kanagy \& Falodun, 2009).

These general results confirm existing empirical evidence by indicating a higher use of CSs by the Beginner Level and thus showing that lower level learners tend to resort to a higher number of CSs than more proficient learners because of their existing deficient command of the L2 (Bialystok \& Fröhlich, 1980; Hyde, 1982; Haastrup \& Phillipson, 1983; Fernández Dobao, 2001; Safont Jordá, 2001). However, when observing these results in more detail it can be seen that the frequency and especially the types of CSs used by the learners from the three groups differ from what has been generally observed. Although the Beginner Level needed to resort to a higher number of CSs, the Intermediate Level also made a frequent use of the CSs, in contrast to the Pre-intermediate Level as would be expected. It can be seen that the 
results for the Intermediate Level are particularly influenced by the number of CSs in the categories C2 and C3. A tentative explanation for this resides in what has also been observed in the literature in this respect in that not only the number of CSs, but the learners' choice of strategies also seems to be related to the learners' proficiency level (Hyde, 1982; Fernández Dobao, 2001; Safont Jordá, 2001).

With this in mind, the following section attempts to confirm this rationale by analysing the learners' strategic communication through those CSs more employed by each level. For this, the number (frequency) of times each CS was more used by each level within each category will be considered in relation to the total number of times that mechanism was used by the three levels. The CSs exemplified in each subsection have been underlined. Some of the conventions used in the transcription of the data are the following: $\uparrow$ indicates rising intonation, \{\} show the researcher's comment, (word) word in parenthesis indicates that the word was not clearly heard, [] indicate overlapping speech.

\subsection{Learners' strategic behaviour by level of proficiency}

\subsubsection{Beginner Level}

\subsubsection{PSM related to L2 resource deficit}

As seen in Table 3 this CS category was more often used by the Beginner Level. The analysis indicated a more frequent use of 'direct appeal for help' (DAH) and 'code switch' (CS). The former was employed 39 times out of a total usage of 70 times by the three levels, and CS was used 53 times out of a total of 101. Other CSs within this category were also used, but in a lesser extent: 'literal translation' (24 times out of 48 ) and 'message abandonment' (18 times out of 30). The following excerpt illustrates the use of DAH and CS which presented a higher frequency.

example (1) Direct appeal for help and code switch

NNS1: You said you are a bad teacher? No, you are a good teacher

NNS2: But sometimes I don't have the pa paciencia 1 Haha $\{$ looks at his classmates $\}$

NS: The what?

NNS1: Passion?

NNS2: Passion paciencia $\uparrow$ asks the interlocutor

NS: Ahhh patience

NNS2: Patience 
Retrospective comments NNS2: I remembered the word started with 'pa'. I repeat 'patience' because I knew it wasn't 'passion'.

The excerpt above shows the learners' need for resorting to their L1 by means of 'code switch'. Their linguistic deficiency can be seen not only by the problems encountered by NNS2 -through his 'appeals for help'- but also by the inability of the other students to assist their peer, who was finally assisted by the NS who confirmed the word needed. As evidenced in most research, less proficient learners need to rely on their L1, a strategic behaviour which reflects the learners' interlanguage stage as still nearer the surface due to their restricted L2 knowledge (Fernández Dobao, 2004; García Núñez, 2006; Mei \& Nathalang, 2010). A similar outcome was observed in the participants' tendency for 'abandoning their message', a CS which albeit less frequently used, also demonstrates this lack of L2 repertoire in that the learners try to avoid the difficulties found by leaving their message unfinished (Fernández Dobao, 2001; Wannaruk, 2003).

\subsubsection{PSM related to processing time pressure}

From Table 3 it can be seen that this level resorted to this category fairly often. The CSs most used were 'self-repetition', which was employed 21 times (out of 50) and 'unfilled pauses', which was used 32 times (out of 82). The following excerpt illustrates both of these mechanisms.

example (2) self-repetition and unfilled pauses

NNS1: Yeah but I don't know ehhh which lan language 1 I'm going to choose with, in my, with my, in my whole, (o sea...in myy life), so if I, I would like to work in France but I don't know -sighs - haha English is I think is more difficult

Retrospective comments NNS1: when I repeated 'with, my' it was to think of how to continue and say something like 'in my life, in what it's remaining of my study programme', I wanted to say 'my whole life.'

The fact that the Beginner Level learners needed to resort to this type of CSs quite often seems to be related to Dörnyei and Körmos' findings (1998), in that these timegaining mechanisms are more important in L2 communication since the learners' processing of information is less automatised and thus they need more processing time. Fernández Dobao (2004: 186) also observed these mechanisms as particularly useful for lower levels since "they are used to gain time to think of alternative means of expression". A similar behaviour was observed here, as illustrated above, since the speaker needed to 'repeat' words or resort to 'unfilled pauses' -or as another student in particular mentioned 'laughed'- in order to gain time to think of the word needed and be able to continue communicating. This outcome coincides with the few studies which have analysed this type of mechanisms in that less proficient learners usually require more processing time to compensate for their lack of L2 resources (Chen, 1990; Prebianca, 2009). 


\subsubsection{Pre-intermediate Level}

\subsubsection{PSM related to L2 resource deficit}

The Pre-intermediate Level learners more frequently employed only those CSs from category 1, PSM related to L2 resource deficit. These are similar results to those observed for the Beginner Level learners; however, when looking at the CSs used within this category, it was observed that in this level the students favoured slightly more often the use of 'circumlocution' and 'foreignising'.

a) Circumlocution

This strategy was observed as slightly more often used by this level with a frequency of 11 times, out of a total of 16 times - as used by the three levels. From the data analysed it seemed that this CS was useful for the learners to compensate for the lack of specific words needed while communicating in the L2.

example (3)

NS: What did you say?

NNS1: I was asking how to say 'pituto'

NS: ah pi-tu-to \{she repeats it more slowly\}

NNS1: 'pituto' is like when you had something that eh eh eh

NNS2: [is easy to reach like

NS: aha

NNS3: you know certain people in certain place and they, they make favours for $\underline{\mathrm{you}}$

NS: ahh connection!

Retrospective comments NNS1: When I use 'eh' I was thinking of how to explain the word and then I just stopped talking because I didn't know how to continue.

b) Foreignising

This CS was employed 7 times (out of 12 times) by these level learners. Its usage seems to show how these slightly more proficient learners are more able to resort to their existing linguistic background in order to attempt to communicate in the L2, as opposed to the lower level which either abandoned their message or resorted to the L1. 
example (4)

NS: so did you talk to them or just listened?

NNS3: just listen and try to, to be polite and don't eh eh to be disimulet $\uparrow$ To be ignored $\uparrow$

NS: ah right

NNS3: so they don't, they they couldn't know that I was listen to him, to them

Retrospective comments NNS3: I didn't know how to say 'disimular' and as sometimes I could see that English speakers understand many of the cognates, so I just came out with something similar to the word in Spanish just in case it could work.

As can be seen these slightly more proficient learners also found difficulties related to their L2 resources; however, their selection of CSs differs from the Beginner Level. Although the use of these particular CSs does not represent a high frequency of usage, their preference may well evidence the need for employing more cognitively demanding mechanisms which require more knowledge of the L2 (Fernández Dobao, 2001; García Núñez, 2006). This differs to what was observed in Level 1 where the learners tended to use 'avoidance' and 'transfer' types of mechanisms which can be seen as less complex. Fernández Dobao (2001) observed similar results especially in relation to 'circumlocution', concluding that this type of mechanism is cognitively and linguistically more complex since the learners have to make use of their existing resources in order to try to keep the original message. This CS is also said to have a more positive effect on communication as a misinterpretation of the message conveyed is less probable to happen, as opposed to what may occur when using 'transfer' (L1-based messages) or 'avoidance' types of CSs (unfinished messages or omission of information). Something similar, in terms of complexity, can be evidenced in the use of 'foreignising'. In the excerpt above it can be seen that this mechanism implies a greater effort on the part of the speaker, who is trying to adapt a word from her L1 into the L2. By doing this, it becomes clear that this type of CS, as 'circumlocution', requires a higher cognitive and linguistic effort, since “it requires a construction process which leads to the creation of a new word" (Dörnyei \& Kormos, 1998: 364). Thus, this outcome seems to demonstrate the learners' progress from the use of less cognitively and linguistically demanding CSs to those considered more complex as their level of L2 competence progresses (Prebianca, 2009).

\subsubsection{Intermediate level}

As presented in table 3, the overall results for this level show that the learners resorted to the CSs less frequently than Level 1, but slightly more than the Preintermediate level. The main differences in terms of CS categories have to do with a higher use of those mechanisms within $\mathrm{C} 2$ and $\mathrm{C} 3$, that is, time-gaining mechanisms and CSs related to problems in the speakers' own output. 


\subsubsection{PSM related to processing time pressure}

In this category, and as opposed to the Level 1 learners, these Intermediate Level learners made more use of fillers, and 'sound lengthening'. The former CS was used 30 times out of a total of 51 times (as used by the three levels), while 'sound lengthening' was employed 8 times out of a total of 12 times.

example (5) Fillers

NNS2: we had ehh, ff, eh English at school but we only had like two hours a week and in two hours you

NNS1: [two hours is not enough]

NNS2: [don't learn]

NNS1: you have to learn by yourself if you want to know like, if you want to be able to speak or to be able to write some piece of writing, for example, you have to learn by yourself.

Retrospective comments NNS1: I said, 'if you want to know' and then didn't know how to continue, that's why I said 'like' to give me time to think of what to say next

example (6) Sound lengthening

NNS1: you said there's not a lot, lot of difference between you and us but I think ehh the problem, the problems about environment ehh eh, they had, you had a difference with us because you concern about it, we don't we don't because we, ah it's, it's like a cultural thing because for example kids or eh, or eh or elderly people eh took theee, ehh that eye-contact with NNS2\}

NNS2: garbage

Retrospective comments NNS1: I do that ('ehh' and lengthened 'the') to be able to continue talking and have the time to think, for example, how to say 'older people' or to give me time for someone else to help me.

This strategic behaviour seems to evidence an important difference with respect to the lower levels in that the more advanced learners need to resort to more elaborated time-gaining devices, as opposed to 'repetition' and 'unfilled pauses', more used by Level 1. This appears to represent these learners' higher level of proficiency since, as mentioned by Dörnyei and Körmos (1998), both CSs are favourable to maintain the flow of the conversation, but also, particularly, the selection of various filling words demands a higher level of complexity. Something similar occurs with 'sound lengthening' which is considered a more elaborate and effective version of 'unfilled pauses' since they are "more effective in holding the floor" (Dörnyei \& Körmos, 1998). The learners are aware of this fact, as can be seen in their retrospective comments. 
One of them mentioned that 'he resorted to fillers quite a lot both in Spanish and English because he knew that they were useful to keep the flow of the conversation and the interlocutor's attention'. Another student said that s/he lengthened the sounds in order 'to gain time to remember specific lexical items or to be able to structure their utterance correctly'. It seems that as these learners do posses more L2 linguistic knowledge -which thus prompts them to try to elaborate more- they need to rely on specific, more efficient, mechanisms for avoiding a break in their communication. Similar results were observed by Khan (2010) whose study indicated that higher levels' communicative desire to express more and more elaborate language pushed them to use more stalling mechanisms to gain time to think of the words needed. Lower levels, on the other hand, resorted to simpler devices as their attention was focused on searching for, and trying to explain, basic linguistic items.

\subsubsection{PSM related to own-output problems}

This type of CS refers to the deficiencies experienced by the speaker in his/her own L2 production. The CS most used within this category by the Intermediate Level learners was 'error-repair' which was used 38 times (out of 66).

example (7)

NS: I heard about that

NNS2: [yeah, and the gas that chile ex, ex, im

NNS1: import

NNS2: import from agentinia, argentina, it's going to be ex, more expensive

NS: the gas?

NNS2: yeah

Retrospective comments NNS2: at the beginning I made a mistake when pronouncing like that Argentina, I think I did it as in French - laughs - so then I corrected myself and after that I corrected myself again when saying 'more expensive'.

Example (8)

NNS1: but fran, French is speaking in very different countries in Africa,

NNS2 \& NNS3: [yeah]

NNS1: not only in France, in Canada, Africa

NS: [Quebec, aha there are a lot of choices

NNS1: 
[E: yeah, in the Caribbean islands called Guadalupe and that it's next to Puerto Rico and they talk, speak in French

NS: [aha

Retrospective comments NNS1: I quickly corrected 'French'. I think that in that moment I did not remember it was 'spoken' or perhaps I got confused. The thing is that sometimes when somebody speaks quickly in a normal conversation, as in Spanish, we say things we know are not right, but we say them anyways, now that I listen to myself I realise immediately that that is not correct.

The use of the self-repairing mechanism above illustrated seems to present more cognitive and linguistic demands since it involves a complete or partial reformulation of the original verbal plan as well as self-monitoring of the speakers' own output (Dörnyei \& Körmos, 1998). This behaviour on the part of the more proficient level confirms again the relationship between their proficiency level and CS usage. These learners' strategic communication evidenced higher linguistic demands which were reflected in their longer and more elaborated interventions as well as in the varied conversation topics. This not only demonstrates their higher command of the L2, but also their higher communicative demands when trying to produce more and more complex language, which made them encounter more communication problems, and concurrently, pushed them to rely on more effective stalling mechanisms. Similar findings have been observed in other studies where more proficient levels have been found more likely to monitor their own output and therefore able to repair their own L2 speech (Poulisse, 1999; Prebianca, 2009; Khan, 2010). Learners are more likely to repair those instances which they consider more serious, and which therefore require more effort on their part. Additionally, they will tend to focus on correcting errors which may impede communication (Poulisse, 1990), all aspects which correspond with the learners' proficiency level. Finally, it should also be considered that the higher language complexity evidenced by this level may have been influenced by the type of task - a free conversation activity. This factor has also been found to play an important role in the learners' selection and quantity of CSs (Fernández Dobao, 2001, 2004; Safont Jordá, 200; Rabab’ah \& Bulut, 2007) however; it is an issue that goes beyond the scope of this study.

\section{CONCLUSION}

This study made it possible to analyse the CSs used by different level L2 English learners in interaction with a NS. The quantitative results obtained confirmed an association between the learners' proficiency level and their CS usage. This relationship was also corroborated through the qualitative analysis of the learners' interactions, thus supporting existing evidence (Bialystok \& Fröhlich, 1980; Hyde, 1982; Haastrup \& Phillipson, 1984; Fernández Dobao, 2001; Safont Jordá, 2001). As expected, the main finding of this study indicates that the lower level learners -because of their 
limited command of the L2- resorted to a higher number of CSs than the more proficient learners. However, a closer look at the results revealed that, contrary to what was expected, the higher level learners resorted to a slightly higher number of CSs than the Pre-intermediate Level. This outcome also corresponds with other studies, which have concluded that more important than the relationship between proficiency and frequency of CS usage is the learners' choice of CSs, which also seems to be related to their proficiency level (Hyde, 1982; Fernández Dobao, 2001; Safont Jordá, 2001). The different mechanisms selected by the different levels appears to corroborate, on one hand, the fact that as the learners' proficiency progresses their strategic behaviour requires more complex types of strategies. On the other, it helps to demonstrate the interlanguage stages that learners go through. The Beginner Level learners tended to favour 'avoidance' and 'transfer' type of CSs whose usage not only demonstrate their less proficient command of the L2, but also their reliance on the L1. The Pre-intermediate Level learners seemed to be in the process of approximating their $\mathrm{L} 2$ production to that of the TL. This was reflected in their attempts to explain/ exemplify the L2 terms needed as well as to adapt their resources to the TL. The Intermediate Level learners, on the other hand, were the only ones who made more use of a more complex mechanism. This appears to indicate their closer approximation to the TL as their wider linguistic repertoire allowed them to correct and evaluate their own L2 output, something the lower levels were not yet able to do. Hence, it seems that these English L2 learners needed to resort to different CSs -in order to tackle different types of communication problems- as their IL progressed towards the mastery of the L2 (Prebianca, 2009).

Another fact worth mentioning has to do with the interactional aspect of this study. As observed in most of the excerpts above presented, as well as in the transcripts of the conversations, the simulation of a more natural setting prompted the learners' communication thus their use of CSs in order to try to solve the difficulties encountered. As opposed to the procedures followed by most research, the use of a free conversation activity in this type of context proved to be useful for the elicitation of the CSs.

Finally, it should be added that even though this was a small scale study - and its results cannot be generalised -it shows the importance of observing L2 learners' strategic communication. By doing this, not only can learners' IL development be perceived, but most importantly, the problems they encounter when using the language in each of these stages. This type of information could be very valuable in pedagogical contexts, where communicative and learner-centred teaching methodologies are becoming more influential, as it could guide teachers on the specific problems their students experience when communicating. 


\section{REFERENCES}

Balharry, G. (2006). The use of lexical communication strategies in the performance of oral tasks by learners of English as a Second Language. Unpublished master's thesis, Universidad de Chile, Santiago, Chile.

Bialystok, E. \& Fröhlich. M. (1980). Oral communication strategies for lexical difficulties. Interlanguage Studies Bulletin, 5, 3-30.

Canale, M. \& Swain, M. (1980). Theoretical bases of communicative approaches to second language teaching and testing. Applied Linguistics, 1(1), 1-47.

Corder, S. P. (1983). Strategies of communication. In C. Faerch \& G. Kasper (Eds.), Strategies in Interlanguage Communication (pp. 15-19). London \& New York: Longman.

Chen, S.-Q. (1990). A study of communication strategies in interlanguage production by Chinese EFL learners. Language Learning, 40(2), 155-187.

Doddis, A., Novoa, P. \& Tabilo, X. (2001-2003). Lexical strategies of communication in the oral production of English as a second language learners: A longitudinal study. Lenguas Modernas, 28-29, 213-228.

Dörnyei, Z. \& Kormos, J. (1998). Problem-solving mechanisms in L2 communication. Studies in Second Language Acquisition, 20(3), 349-385.

Ellis, R. (1997). Second language acquisition. Oxford: Oxford University Press.

Ellis, N. C. \& Robinson, P. (2008). An introduction to cognitive linguistics, second language acquisition, and language instruction. In N. C. Ellis \& P. Robinson, (Eds.), Handbook of Cognitive Linguistics and Second Language Acquisition (pp. 3-24). Oxford: Routledge.

Færch, C.\& G. Kasper. (1983). Plans and strategies in foreign language communication. In C. Færch \& G. Kasper (Eds.), Strategies in Interlanguage Communication (pp. 20-60). London \& New York: Longman.

Fernández Dobao, A. M. (2001). Communication strategies in the interlanguage of Galician students of English: The influence of learner- and task- related factors. Atlantis, 2(1), 41-62.

Fernández Dobao, A. M. (2004). The use of communication strategies by Spanish learners of English. A study of the collaborative creation of meaning, language, and linguistic knowledge. Unpublished doctoral dissertation, Universidad de Santiago de Compostela, Spain. 
Fernández Dobao, A. M. \& Palacios Martínez, I. M. (2007). Negotiating meaning in interaction between English and Spanish speakers via communication strategies. Atlantis, 29(1), 87-105.

Gass, S. \& Mackey. A. (2000). Stimulated recall methodology in second language research. New York \& London: Routledge.

García Núñez, W. (2006). El uso de las estrategias de comunicación oral y el nivel de dominio del idioma inglés. Revista Perfiles, 27, 97-123.

Haastrup, K. \& Phillipson, R. (1983). Achievement strategies in learner/native speaker interaction. In C. Færch \& G. Kasper (Eds.), Strategies in Interlanguage Communication (pp.140-158). London \& New York: Longman

Hyde, J. (1982). The identification of communication strategies in the interlanguage of Spanish learners of English. Anglo-American Studies, 2(1), 13-30.

Kellerman, E., Ammerlaan, T., Bongaerts, T. \& Poulisse, N. (1990). System and hierarchy in L2 compensatory strategies. In R. Scarcella, E. Andersen \& S. Krashen (Eds.), Developing Communicative Competence in a Second Language (pp. 163-178). Boston, Massachusetts: Heinle \& Heinle Publishers.

Khan, S. (2010). Strategies and spoken production on three oral communication tasks: A study of high and low proficiency EFL learners. Unpublished doctoral dissertation, Universitat Autónoma de Barcelona, Spain.

Labarca, A. \& Khanji, R. (1986). On communication strategies: Focus on interaction. SSLA, 8, 68-79.

Lafford, B. A. (2004). The effect of the context of learning on the use of communication strategies by learners of Spanish as a second language. SSL $A, 26,201-225$.

Littlemore, J. (2003). The communicative effectiveness of different types of communication strategies. System, 31, 331-347.

Long, M. H. (1980). Input, interaction and second language acquisition. Unpublished doctoral dissertation, University of California, Los Angeles, USA.

Mei, A. \& Nathalang, S. (2010). Use of communication strategies by Chinese EFL learners. Chinese Journal of Applied Linguistics, 33(3), 110-125.

Paribakht, T. (1984). The relationship between the use of communication strategies and aspects of target language. Québec: International Centre for Research on Bilingualism.

Pica, T., Kanagy, R. \& Falodun, J. (2009). Choosing and using communication tasks for second language instruction. In K. Van Den Branden, M. Bygate \& J. M. Morris (Eds.), Task-based Language Teaching (pp.171-192). Amsterdam/ Philadelphia: John Benjamins. 
Poulisse, N. (1990). Variation in learners' use of communication strategies. In R. Duda \& P. Riley (Eds.), Learning Styles, First European Seminar (pp. 77-87). Nancy: Universitaires de Nancy.

Poulisse, N. \& Schils, E. (1989). The influence of task- and proficiency-related factors on the use of compensatory strategies: A quantitative analysis. Language Learning, 39(1), 15-47.

Prebianca, G. V. (2009). Communication strategies and proficiency levels in L2 speech production: A systematic relationship. Revista de Estudos da Linguagem, 17(1), 7-50.

Rabab'ah, G. \& Bulut, D. (2007). Compensatory strategies in Arabic as a second language. Poznán Studies in Contemporary Linguistics, 43(2), 83-106.

Rabab'ah, G. \& Seedhouse, P. (2004). Communication strategies and message transmission with Arab learners of English in Jordan. Annual Review of Education, Communication and Language Sciences [on line]. Retrieved from: http:// research.ncl.ac.uk/ARECLS/vol1_documents/Ghaleb\&Seedhouse/Ghaleb $\&$ Seedhouse.htm

Safont Jordá, M. P. (2001). An analysis on the use and selection of communication strategies by Catalan/Castilian learners of English. Rassegna Italiana di Linguistica Applicata, 1(1), 57-72.

Selinker, L. (1972). Interlanguage. IRAL, 10(3), 209-231.

Tarone, E. (1977). Conscious communication strategies in interlanguage: A progress report. In H. Douglas Brown, C. A. Yorio \& R. H. Crymes (Eds.), TESOL'77: Teaching and learning English as a Second Language (pp.194-203). Washington D.C.: TESOL.

Tarone, E. (1981). Some thoughts on the notion of communication strategies. TESOL Quarterly, 15(3), 285-295.

Tardo, Y. (2005). Potenciar las estrategias comunicativas en las clases de ELE: Una opción viable para desarrollar las habilidades orales. RedELE, 5 [on line]. Retrieved from: http://www.mecd.gob.es/redele/revistaRedEle/2005/ tercera.html

Váradi, T. (1973). Strategies of target language communication: Message adjustment. Paper presented at the $\mathrm{VI}^{\text {th }}$ Conference of the Rumanian-English Linguistics Project, Timisoara.

Wannaruk, A. (2003). Communication strategies employed by EST students. SLLT, $12,1-18$. 
Williams, J., Inscoe, R. \& Tasker, T. (1997). Communication strategies in an interactional context: the mutual achievement of comprehension. In G. Kasper \& E. Kellerman (Eds.), Communication Strategies, Psycholinguistic and Sociolinguistic Perspectives (pp. 304-322). London \& New York: Longman.

Wongsawang, P. (2001). Culture-specific notions in L2 communication strategies. Second Language Studies, 19(2) 111-135.

Yang, D. \& Gai, F. (2010). Chinese learners' communication strategies research : A case study at Shandong Jiaotong University. Cross-Cultural Communication, 6(1), 56-81.

\section{APPENDIX}

\section{Cuestionario sobre conocimiento lingüístico previo del idioma inglés}

Estimado alumno,

Por favor solicitamos contestar las siguientes preguntas encerrando en un círculo la opción que estime más adecuada en su caso. La información entregada será de mucha utilidad para este proyecto de investigación.

La información y todos los antecedentes recogidos serán de carácter estrictamente confidencial.

En caso de contestar SÍ a alguna de las preguntas, por favor indicar información en espacio siguiente.

Gracias,

Equipo de Investigación

1. Nombre:

2. ¿Qué año cursa de la Carrera de Traducción/Interpretación?
a) 1 er año
b) $2^{\circ}$ año
c) 3er año

3. ¿Estudió en Colegio Bilingüe?
a) Sí
b) No

Indicar: 
4. ¿Hablaba inglés previo a su ingreso a la Universidad?
a) Sí
b) No

Indicar:

5. ¿Vivió en algún país de habla inglesa previo a su ingreso a la Universidad?
a) Sí
b) No

Indicar:

6. ¿Asistió a cursos de inglés en algún instituto previo a su ingreso a la Universidad?
a) Sí
b) No

Indicar: 